\title{
RELIGIOUS-BASED HIGHER EDUCATION INSTITUTION AND HUMAN RESOURCE DEVELOPMENT: A Case Study of Universitas Pesantren Tinggi Darul Ulum Jombang (UNIBDU)
}

\author{
Samsul Ma'arif \\ Universitas Islam Negeri Sunan Ampel Surabaya \\ Email: samsul_jombang@yahoo.com
}

\begin{abstract}
The role of higher education is very crucial in developing human resource because it is a future investment which has great effect on the improvement of real sector. Higher education is proven to be an effective agent of social change. In human resource management, the role of higher education is embodied in community service program which is more known as "Tri Dharma Perguruan Tinggi" including acquisition, transmission and application. Human Resource management is basic administrative description or educational management based on a series of interrelated processes in guiding the behavior of individuals as the member of an organization in order to achieve its goals. The process can be identified as follows: planning, compensation, recruitment, selection, induction, appraisal, development, maintenance, performance, security, integration, and information.
\end{abstract}

Keyword: Higher Education, Education, Human Development

\section{INTRODUCTION}

Islamic Higher Education constitutes one of human civilization forms. Civilized society tends to develop varied institutions to excavate, develop, transform and apply science for public prosperity, and in this context, higher education has the most important role. Besides, it is an institution which develops social development knowledge as a part of science and technology.

Previously, higher education is only a community of experts and students which focuses on teaching moral and humanity, but later it is named as modern university by Kerr according to organism model of Abraham Flexner's research (Keer, 1982; 2). By the presence of this modern university, science replaces the role of philosophy; research replaces teaching; and specialization replaces generalization, Flexner. Higher education is an institution which 
serves science, finds solution, and appreciates critically to achievement and high training (Keer, 1982; 4).

Further, Islamic higher education is an institution consisting of various communities and activities: community of diploma, undergraduate, and postgraduate degree, community of humanities and social science, community of professional academician, and community of non-academic and administrative staff.

In Indonesia, the nature of higher education is mentioned in the constitution number 20, year of 2003 regarding the national education system article 1, verse 19: higher education is further level of senior high school which is held to prepare students in order to be a member of society who has academic ability, and is professional to apply, develop, and create science, technology, and art. It is an institution which has three main missions; they are education and teaching, research, and social service.

These missions, according to Perkins, are based on three aspects of knowledge: acquisition, transmission, and aplication. Knowledge is obtained through research process, and is taught to future generations in order to survive. It is then transformed and applied so that it will be useful. Meanwhile, social service programs are a right place to apply the knowledge in order to develop the society. The three missions are popular as tridharma perguruan tinggi.

Islamic higher education is an organization that assists children or group of people to have good personality, think, decide, and act according to Islamic teaching and law (Zuhairini, 1995).

It is also defined as an educational institution in which its learning programs are based on Islamic perspective and values (Buhori, 1989). It means that Islamic educational institution is all activities of an organization or institution to internalize Islamic values to Islamic students.

One of Islamic education institutions is pondok pesantren led by kyai. It teaches, develops, and spreads Islamic knowledge (Zuhairini, 1995). It has been existing for long time and is very influential especially among villagers in Indonesia. It is also a home stay for santri, and is usually near to kyai's house or mosque. The word pesantren is derived from word 'santri' which is added with prefix $p e$ - and suffix -an then turns into pe-santri-an, and eventually becomes pesantren or a place for santri. Meanwhile, the word santri is derived from Tamil word means the expert of Hindu holy book. Nowadays, the term 'santri' is student who stays at boarding house (pondok), except those who live near pesantren. Further, santri is considered as a religious group, and is the opposite of abangan (Geertz, 1981;172). 
Wahid states that pesantren is a separate place from its surroundings (Wahid, 2001). It consists of residence for the caretaker (known as kyai in Java, ajengan in Sunda, nun or bendara/ra in Madura), mosque, and dormitory. The fundamental elements of pondok pesantren are kyai, santri, pondok, and mosque, while modern pondok pesantren also provides formal education/ school.

Types of pesantren include traditional and modern pesantren. According to Sudjoko there are four types of pesantren namely type I: mosque and kyai's house; type II: mosque, kyai's house, and pondok; type III: mosque, kyai's house, pondok, and school; and type IV: mosque, kyai's house, pondok, school, university, hall, sport center, and so on. Type III and IV are more likely able to deal with global competition (Sudjoko, 1974:47)..

Generally, based on its educational form pesantren comprises salafiyah and khalafiyah. Salafiyah only exposes religious teaching, while the latter is considered as modern pesantren which not only teaches religious knowledge but practical skill as well. Pesantren along with its elements is an educational, da'wa, and social institution coloring the life of villages. It grows and develops with society for centuries (Hasan, 1989: 49).

Its presence is in accordance with the dynamic development of society, and is a solution to social problems. Meanwhile, the existence of higher education cannot be separated with the presence of pondok pesantren since it is an embryo of Islamic higher education in Indonesia, particularly Java.

\section{THE ROLE OF HIGHER EDUCATION IN COMMUNITY DEVELOP- MENT}

One of the three higher education's missions is to educate students in order to be able to improve their reasoning, knowledge, science, dedication, and responsibility which are developed through research, and is aimed for social benefit. Meanwhile, community service program is the implantation of science and technology in developing community, and is a proof of higher education' concern as a reflection of social dynamics.

Rifai affirms that higher education, in the context of community development, is center of creativity according to sense of purpose, sense of mission, and sense of commitment, and gives contribution to social intellectual modernization (Rifa 'i, 1996). Further, it does not compromise with conservative ideas, intellectual conformity center or soulless building. Community development should be followed with the reform of social culture and economics along with quantitative and qualitative aspects. The process of community modernization includes social and psychological changes are more suitable with new political, 
economic, and social structure condition. Therefore, Islamic higher education must play active role, and be able to create change designer and pusher as entrepreneur and innovator.

\section{THE ROLE OF HIGHER EDUCATION IN LONG-TERM DEVELOPMENT PLANNING}

The role of higher education in long-term development planning is as a center of science and social development, and organizer and developer of higher education, science, technology and art. Campus as scientific community aims to create well-educated people and conducts beneficial research for community life standard improvement. Hence, higher education is expected to be a qualified and professional center of community development in order to deal with the needs of complex high development.

Almost all campuses constitute center for potential professionals in developing the surrounding people through research, collection, and data analysis. For that, higher education can be an active center of community information and development.

Higher education is a center of culture which is in accordance with the main guidance of culture of UN (1986): 1) strong national cultural values awareness is marked with the development of technology and global economic order; and 2) firm national identity awareness is marked with the legacy of upright values, historical consciousness, and creative power.

Higher education has instrumental role to achieve the goal for it is a guiding place for intellectual community to learn science, technology, and art. Therefore, the community should have both social professional and intellectual competence. Social professional competence consists of concept, behavior, and science and technology applicator, while the intellectual competence includes awareness of social and environmental problem and truthful concept and common interest of society.

\section{DEVELOPING HUMAN RESOURCE}

Indonesia has huge problems in developing human resource in which this country must face globalization and also economic crisis that leads to political and social crisis and even disintegration of the nation. National reform movement has changed the policy of national development into democracy, admitted human equity, and implemented decentralization. The change has caused micro and macro problems of education. Micro problem is quality of 
education while macro problem is related to decentralization and management of education.

The main character of Indonesian people is that they are democratic, and uphold values of humanity, equity and justice, tolerance, and law enforcement (Fadjar, 2001;24). Hence, individual and community need developing because independent society requires motivation, strong capability and active participation. In this case, education is believed a most influential factor to empower the individual and community.

The factors comprise 1) holistic human development including adaptive survival skill; 2) community education development that grows historical perspective: the awareness of needed values to create Indonesian independent society; and 3) mass education development through the use of mass media: printed or electronic media.

During the transformation process, education must be able to give optimum contribution in creating independent community. Therefore, complete philosophy is required to balance between education and community dynamic change. In this case, education includes three processes of learning, economics, and socio culture.

Meanwhile, global environment is marked with open market system based on rapid change and advanced information technology application. Besides, the need of qualified human resource is increasing in line with fast transformation of environment. Further, national crisis consists of four aspects: economic, politic, law, and socio-cultural reform.

Therefore, the new paradigm and development goal in national education system is required. Previous paradigm is centralistic, top down, partial, economic development, politic stability, and assembling technology oriented, government dominant role, and low non-school institution role, while new paradigm is autonomous, bottom-up, holistic development oriented, varied cultural tolerance, upholding moral value, enforcing humanity and religion, creative, productive, and juristic (Jalal \& Dedi S, 2001).

The principles contained in the new paradigm is a) equality between education sector with other sector, b) social reconstruction oriented, c) national development, d) social infrastructure empowerment, e) qualified independent culture, f) good condition for tolerance, consensus, and diversity, g) integrated horizontal and vertical planning, h) learner centered, i) multi-cultural education, and j) education according to global perspective (Castetter, 1991; 316). 


\section{THE EFFECT OF HUMAN CAPITAL INVESTMENT ON INCOME}

Salary or income of a person is decreasing according to his age in every sector. In the future, human will be more productive and skillful, and will be paid based on his capacity. Meanwhile, those who are unskillful will only become marginal spectators.

\section{EDUCATION AND HUMAN RESOURCE TRAINING}

Education and training is a medium to improve working productivity which leads to better profit. The good productivity is caused by education and training, and skillful workers will be paid higher than who are unskillful. The unskillful workers will be trained by job training bureau. The training is believed to give rate and return of investment in certain period.

Education provided by the school is a more comprehensive human of investment. It is very time consuming, and requires high tuition in the form of opportunity cost. In this case, higher education is more able to prepare welleducated individuals to deal with working market with higher salary than those of secondary school graduate. So that, it must have better basic capital such as age and cost.

\section{HUMAN CAPITAL AND FAMILY}

Human empowerment through education cannot be separated from family economic support. Better economic level tends to enable one to have better education level. Further, economic level is influenced by various factors: job, parent, number of children, and education quality. Hence, family has crucial role in human empowerment.

\section{QUALIFIED HUMAN RESOURCE AS EDUCATION INVESTMENT}

Rate of return is an approach often used in education investment research. Some aspects as the result of education are income, productivity, and economic change. Becker even groups the intelligence according to graduate level in three percentage groups: 18, 16, and 20\% (Becker, 1983). The intelligence of elementary school graduate is different from those of junior high school, while senior high school graduate is $30 \%$ than the graduate of junior high school. This result is reflected from prosperous level according to education investment level and qualified human resource. Education investment leads to the improvement of qualified human resource supply, and it requires qualified academic staff. 
Academic staff is a determinant component in empowering human resource according to national education system ${ }^{1}$. His professional capability and performance will contribute not only to quality of graduate (output) but also the performance of the graduate (outcomes). Many studies and research show the central position of academic staff in every educational institution. Castetter stated that staff development is closely related to institusional change, so that education development qualitatively related to the quality of academic staff (Castetter, 1981; 316).

Meanwhile, the managerial function of education is to design, implement, and evaluate teaching and learning result holistically. It is associated with the planning made by academic staff since it is a milestone to get good result, and constitutes one of determinant factors of the success of learning. Besides, planning is one of fundamental managerial functions. Therefore, good education management changes bad situation into good condition, and on the contrary, bad education management turns good condition into bad situation (Uwes, Sanusi, 1999).

Academic staff management is also known as personal management, personal administration, and human resource administration. It is a part of human resource development and a core of administration and management of education. Next, the role of human resource in the process of education is very important because the productivity of education depends so much on its contribution thought its function and activity.

Human resource is basically a description of education management or administration in an interrelated sequence of functions. Morphet et al. identify the functions in following processes: human resourches planning, compensation, recruitment, selection, induction, appraisal, development, maintaining and improving performance, security, union relation, and information. Meanwhile, Randall mentions the functions as follows: planning, staffing, appraising, compencation, and training (Randall, 1987; 29).

\section{METHODS}

This was a descriptive qualitative research, and aimed to depict the role of higher education in developing human resource based on facts found in the research field (Lexy J Moeleong, 2001), A Multi Cases Study at Universitas Pesantren Darul Ulum Jombang. Moreover, this research exposed the reality of the role of higher education in developing human resource, and was conducted at Universitas Pesantren Tinggi Darul Ulum Jombang.

1 (PP. No. 38, 1992) 
Meanwhile, its research subject was the foundation of Pesantren Tinggi Darul Ulum (YAPETIDAR) and Darul Ulum, rector, vice rector, dean, vice dean, departments of the university, general chief of the foundation, caretaker assembly, chief of bureau and unit, head master, vice head master, teacher, and staff.

Next, the data of the research was collected through interview, observation, and document review. Then the data were analyzed using interactive model data analysis: data collection, data reduction, data display, verification or conclusion drawing. To assure the trustworthiness, the researcher conducted triangulation and focus group discussion (FGD).

\section{THE PROFILE}

UNIPDU is the abbreviation of Universitas Pesantren Tinggi Darul Ulum. It is one of accredited private universities; its level of accreditation is B. It was established in Jombang, West Java in 2001 by a charismatic Islamic scholar, K.H. Muh. As'ad Umar who is also known as an Islamic nationalist.

Even it was built inside the pesantren, it is not only good at religious knowledge but also scientific studies. It has reached many achievements in the field of education, research, and community service. The student of faculty of science and mathematics of UNIPDU once became a finalist in Pekan Ilmiah Mahasiswa Nasional (PIMNAS). The organization structure of the university is rector, Prof. Dr. H. Ahmad Zahro, M.A., vice rector I, Ahmad Zakaria, S.K.M., M.Kes., vice rector II, Dr. dr. Zulfikar As'ad, M.M.R., and vice rector III, M. Imsin Al Mustofa, S.E., M.P.

At present, UNIPDU possesses a hospital "RS UNIPDU Medika" inaugurated by Vice President of Indonesia, Drs. H. Muhammad Jusuf Kalla in September 2007. It proves that UNIPDU concerns people health. Even, former rector of UNIPDU, Prof. Dr. H. Ahmad Zahro, M.A., stated that the campus will have faculty of medicine. Besides, pondok pesantren Darul Ulum consists of Islamic and public elementary, secondary, and tertiary level of education.

\section{DISCUSSION}

This research focuses on a) "How does UNIPDU face the future?" and b) "What is the role of UNIPDU in developing human resource?" UNIPDU is a center of human resource development. This is shown by its program of community service in which it helps schools around the campus to manage their curriculum, students' activity, learning facility, and achieves. As the result, the schools under the authority of the foundation of pesantren 
Darul Ulum become role model of other schools. This is in line with Rifa'i's statement: the role of higher education in developing human resource is a center of creativity to face the future according to the sense of purpose, sense of mission, and sense of commitment (Rifa' $i, 1986$ ). Therefore, UNIPDU forms several centers of study: center of quranic study, center of language, center of computer technology and internet, and center of ASEAN study. Furthermore, it also actively participates in international forums such as Association Youth Interfaith Camp, and is one of 20 Asian leading universities.

The role of UNIPDU in developing human resource through Caturdarma Perguruan Tinggi: 1) Education and Instruction, 2) research, 3) community service, and 4) Islamic study. The university involves the nuance of pesantren in instructional activity. It has 2 diploma/D3, 11 undergraduate/S1, and 1 postgraduate/S2 programs which are accredited by Badan Akreditasi Nasional Perguruan Tinggi (BAN-PT) or National Accreditation Board for Higher Education: 1) Faculty of Islamic Studies, Department of Islamic Education, Undergraduate/S1 Program (accreditation 'B'); Department of Islamic Elementary Teacher Training, Undergraduate/S1 Program (accreditation 'B'); and Department of Ahwal Asy-Syakhsiyah Undergraduate/S1 Program (accreditation 'B'); 2) Faculty of Technique, Department of Information System, Undergraduate/S1 Program (accreditation 'C'); 3) Faculty of Administration Science, Department of Commerce Administration, Undergraduate/S1 Program (accreditation 'C'); Faculty of Language and Letters, Department of English Letters, Undergraduate/S1 Program (accreditation 'C'), Department of Japanese Language, Diploma/D3 Program (accreditation 'B'), and Department of English Education Undergraduate/S1 Program (accreditation 'C'), and 4) Faculty of Medicine, Department of Nursery Undergraduate/S1 Program (accreditation 'B'), Department of Midwifery Diploma/D3 Program (accreditation 'B'), and Department of Nursery Diploma/D3 Program (accreditation 'B'); 5) Faculty of Natural Science and Mathematics, Department of Mathematic Education, Undergraduate/S1 Program (accreditation ' $\mathrm{C}$ '); Department of Mathematics, Undergraduate/S1 Program (accreditation 'C'); and 6) Graduate Program of Islamic Education (accreditation 'B').

Next, UNIPDU has 6 lecturers having master degree, and some lecturers with Ph.D. degree. This in line with Castetter's statement: staff development is closely related to institusional change so that the development of education qualitatively related with the quality of the academicians (Castetter, 1981; 316).

Academic and non-academic activities of the university is according to standard operating procedure (SOP) such as lecturing activity, community 
service, research, scientific paper writing (guideline of script and thesis), and financial management. Those activities are under the supervisory of quality insurance unit. Meanwhile, in promoting human resource the campus holds following workshops: workshop of performance, lesson plan design, and field trip. Besides, it also cooperates with other institutions and individuals based on the sense of brotherhood and tolerance. In order to maintain the health of its all members, the university conducts several programs: a) gymnastics, b) health guidance, c) maintenance of environment cleanliness, and d) lunch gathering. For the financial transparency, it uses networking application. Further, it gives reward for good performing staffs, and provides training to teachers of public and Islamic elementary and secondary schools. It also provides $25 \%$ scholarship for teacher who has working at the institution for 5 years and 50\% for those who has working for 10 years. This is in accordance with Kepmendiknas No. 13 year of 2007 which states that the academic degree standard of headmaster is master degree/S2 (Permendiknas, 2007).

Moreover, UNIPDU develops students competence through workshops based on the concept of tafaqquh fiddien. It means that the graduates of the university will have professional competence and behave according to Islamic teachings so that they can manage to get suitable job and position. Besides, such a competition is required by companies as the user of the graduates. Further, as a pesantren based university, UNIPDU provides higher education as comprehensive human investment. Even it requires students to pay tuition as opportunity cost, yet when working, its graduates will be paid higher than those of elementary or secondary school.

The research focus of the university is on science and technology development, and is conducted according to the principles of cooperation, way of thinking, active and creative work, and sustainable contribution. The campus provides research funds, 5 million rupiahs for beginner, and 40 million rupiahs for intermediate researcher and 100 million rupiahs for advance researcher. Meanwhile, community service program conducted by the university is based on Islamic studies therefore it can be accepted well by the people such as the program of youngster counseling, imam training, quranic learning center management, Al-Qur'an recitation training, and so forth.

The community service program is intended to create agent of change to achieve short, middle, and long term goals. Therefore, it is implemented based on the principle of community development or social design aimed at enabling people to be independent. It includes religious guidance or da'wa and entrepreneurship.

The Fourth Dharma is having qur'anic recitation at 12.00 a.m. after zhuhr 
prayer and delivering Islamic speech. The function and role of Caturdarma Perguruan Tinggi of the campus are interrelated. If one of them is missing it will be less qualified. Thus, all members of the university must actively participate in improving academic quality of the campus.

The function and role of higher education is to guarantee the students' quality in order to satisfy the stake holder. To assure the quality of lecturing performance, the university involves students to audit and assess lecturers' performance when teaching. This assessment is used to identify teaching weaknesses and then find its solution. Usually the assessment is objective for students experience instructional process so that they can give their real opinion about the process; whether or not it is satisfied.

\section{CONCLUSION}

UNIPDU (Universitas Pesantren Tinggi Darul Ulum) as a higher education constitutes a center of creativity which is expected to prepare students to face the future by contributing in intellectual and social development based on following senses: sense of purpose, sense of mission, and sense of commitment. The role of UNIPDU in developing human resource is by creating independent and innovative change designers and pushers who have good behavior according to akhlaqul karimah. Hence, the campus implements the fourth darma: pesantren based Islamic studies.

\section{BIBLIOGRAPHY}

Becker, S. Garry. 1983. Human Resources Development: A Theoretical and Empirical Analysis with Special References to Education.

Bukhori,1989. Pendidikan Islam di Indonesia; Problem Masa Kini dan Prspektif Masa Depan, Dalam Islam Indonesia Menatap Masa Depan. Jakarta: P3M.

Castetter, William B. 1981. The Personnel Function in Educational Administration. New York: mac. MillanPublishing co.

Fadjar, A. Malik. 2001. Paradigma Pendidikan Islam Menuju Masyarakat Madani”. Mimbar Kampus, Jurnal pendidikan dan Agama. Bogor” STAI Laa Roiba,

Geertz, C. 1981. .Abangan, Santri, Priyayi dalam masyarakat Jawa. Jakarta: Rujukan Jaya.

Hasan, N. 1988. Karakter dan Fungsi Pesantren. Dalam dinamika Pesantren. Jakarta: P3M. 
Jalal, Fasli \& Dedi Supriadi. 2001. Reformasi Pendidikan dalam Konteks Otonomi Daerah. Yogyakarta: Depdiknas, Bappenas, Adicita Karya Nusa.

Keer, C. 1982. The use of the University 93 rd ed). Cambridge: Massachusetts: Harvard University press.

Peraturan Menteri Pendidikan Nasional No. 13 Tahun 2007 Tentang Standar Kepala Sekolah.

Moleong, Lexy J., 2001 Metodologi Penelitian Kualitatif, Bandung; PT Remaja Rosdakarya,

Pusposutardjo, Suprodjo. Kebijakan Pengembangan Pendidikan Tinggi di Era Kehidupan Mendunia. Jakarta: Depdiknas.

Raharjo, MD, 1983. Pergulatan DuniaPesantren, Membangun dari Bawah, Jakarta: P3M.

Schuler, Randall. 1987. Personnel and Human Resourches Management. St. Paul USA: west Publishing Companny.

Uwes, Sanusi. 1999. Manajemen pengembangan mutu Dosen. Jakarta: Logos.

Wahid, 2001, Bunga Rampai Pesantren, Jakarta,Darma Bakti.

Zuhairini, 1995. Sejarah Pendidikan Islam Di Indonesia, Proyek Pembinaan Prasarana dan Sarana Perguruan Tinggi Agama Islam/ IAIN 